\title{
Stratigraphy and age of the Grippia niveau bonebed, Lower Triassic Vikinghøgda Formation, Spitsbergen
}

\author{
Bitten Bolvig Hansen ${ }^{1}$, Øyvind Hammer' \& Hans Arne Nakrem \\ ${ }^{1}$ Natural History Museum, P.O. Box 1172 Blindern, NO-0318 Oslo, Norway. \\ E-mail corresponding author (Bitten Bolvig Hansen): b.b.hansen@nhm.uio.no
}

We report on a newly excavated Spathian (Lower Triassic) bonebed on Marmierfjellet, Central Spitsbergen. The bonebed contains a varied material of bones and teeth from marine vertebrates along with conodont elements. The fauna of the bonebed could prove interesting in a global context of recovery and speciation after the Late Permian mass extinction. For this reason it is important to place the bonebed in a stratigraphic and chronologic framework. The bonebed sits within the Grippia niveau and is likely to be the one first described by Stensiö in 1921. The bonebed and the Grippia niveau are part of the Vendomdalen Member of the Vikinghøgda Formation. Based on the level in the stratigraphy, the bonebed most likely correlates to the Bajarunia euomphala Zone or the Parasibirites grambergi Zone which makes it either early or early/middle Spathian in age. Some conodont elements from the bonebed are reworked from older sediments but the youngest found are supporting a Spathian age. Vanadium data and TOC content from the bonebed indicate that it was formed under increasingly anoxic conditions.

Keywords: Early Triassic, Spathian, Svalbard, bonebed, chemostratigraphy

Received 23. November 2017 / Accepted 7. July 2018 / Published online 4. October 2018

\section{Introduction}

The Triassic deposits in Svalbard have received attention from both geologists and palaeontologists since the 19th century. The first truly robust stratigraphic scheme was presented by Buchan et al. in 1965 and later revisions have built upon this foundation (e.g., Mørk et al., 1999). Buchan et al. (1965) made thorough attempts to include all earlier named units and place them in the new stratigraphy. However, the stratigraphic scheme for the Lower Triassic still suffers problems in terms of precise placement of fossiliferous horizons. Bonebeds and fossiliferous intervals have not been consistently described historically and it remains difficult to place them precisely in relation to geological units. For the Lower Triassic of Central Svalbard, three named levels have been in use among palaeontologists since the 1930s. The Fish niveau and the Lower Saurian niveau were named by Wiman (1910) who did important palaeontological work in the Triassic of Svalbard in the early twentieth century. The
Fish niveau is now synonymous with the upper part of the Lusitaniadalen Member of the Vikinghøgda Formation and has a fairly well-defined upper boundary whereas the extent downwards is still somewhat unclear. The Lower Saurian niveau lies at the top of the Vendomdalen Member of the Vikinghøgda Formation but the exact placement and thickness was not resolved until recently. Consecutive authors have placed it partly in the Vikinghøgda Formation and partly in the overlying Botneheia Formation (Maxwell \& Kear, 2013). Engelschiøn et al. (2018) interpret a $1 \mathrm{~m}$-thick fossiliferous interval lying 2 $\mathrm{m}$ below the top of the Vendomdalen Member to be the Lower Saurian niveau and describe no related fossil finds in the Botneheia Formation. Between the Fish niveau and the Lower Saurian niveau a third level, the Grippia niveau, should be located. It was first mentioned by Stensiö (1921) as a local bonebed and further described by Wiman (1928, 1933). This fossiliferous level is characterised by a rich content of small basal ichthyopterygians that have been lumped together in the taxon Grippia (Maxwell \& Kear, 2013) see also Hurum et al. 2018). 
From 2004 to 2016 the Norwegian-based Spitsbergen Mesozoic Research Group has worked with palaeontological excavations in the Mesozoic of Svalbard. Different palaeontological problems have been in focus but the main interest has been on Triassic and Jurassic marine reptiles that lived in the Boreal Ocean. In 2014, the group discovered a Lower Triassic bonebed deposit on Marmierfjellet in Central Spitsbergen. The deposit contains well-preserved remains of a diverse marine fauna (Bratvold et al., 2018; Ekeheien et al., 2018) whereof the most iconic taxa are the basal ichthyopterygians. The bonebed is located on the western slope of Marmierfjellet within Flowerdalen and consists of disarticulated bone material, teeth, phosphate nodules and partly unconsolidated silty sediment. The bonebed was excavated partly in 2015 and again in 2016. The latter excavation was the largest, exposing and recovering about $27 \mathrm{~m}^{2}$ of bonebed. The dig site had a lateral extent of $9 \mathrm{~m}$ exposing the entire main portion of the 'true' bonebed deposit with characteristic phosphate nodules and unconsolidated sediment. Immediately to the north of the excavation, the true bonebed deposit rapidly pinched out and disappeared. However, some scattered bones could still be found on the surface along the mountainside at the same stratigraphic level. The bones weather directly out of the shale. To the south of the excavation, the bonebed deposit gradually thinned out over a distance of about fifty metres. Beyond this point, the stratigraphic level could be followed based on scattered bone finds in a similar way as to the north. The rich occurrence of basal marine reptile bones along the mountain side at the same level as the true bonebed deposit has led us to believe that we may have located the bonebed originally described by Stensiö (1921).

Lower Triassic deposits around the globe have long been thought to be characterised by low species diversity and dominance of disaster-taxa following the PermianTriassic crisis. However, new findings have started to change our view of the Early Triassic recovery (e.g., Song et al., 2011; Brayard et al., 2017). It is an open question whether the highest trophic levels recovered shortly after the crisis, remained absent until far into the Early Triassic or if modes of recovery can be compared between regions (e.g., Chen \& Benton, 2012). Fossil remains of various trophic levels - especially apex predators - from the bonebed on Marmierfjellet are significant in the mapping of the global recovery after the Permian-Triassic crisis. A precise dating of the bonebed is thus crucial for correlations and comparisons between the Boreal Ocean and other regions. However, the relative dating of sediments in Svalbard is hampered by the extreme discontinuity of the fossil record. This fact makes ammonoid, conodont and palynological zones difficult to identify in the Lower Triassic deposits of the Boreal Realm (e.g., Mørk et al., 1999; Nakrem et al., 2008; Vigran et al., 2014).
In this article we present lithological, palaeontological and geochemical data from the bonebed deposit on Marmierfjellet and discuss correlation, age and palaeoenvironmental implications of these results.

\section{Geological setting}

The Vikinghøgda Formation of central Spitsbergen, Barentsøya and Edgeøya consists of sandy siltstones grading into silty grey shales and black shales. Horizons of calcareous nodules and benches are widespread in the Lusitaniadalen and Vendomdalen members. The Vikinghøgda Formation was formed in a shallowmarine setting of gradual deepening as seen from the reducing grain sizes and increasing organic content upwards through the succession. The lowest Deltadalen Member is Induan in age, while the Lusitaniadalen and Vendomdalen members are Olenekian in age. The boundary between the Smithian and Spathian substages is still not fully resolved but lies near the lithological boundary between the Lusitaniadalen Member and the Vendomdalen Member (Mørk et al., 1999).

The Grippia niveau bonebed described here is located in Flowerdalen on the western slope of Marmierfjellet at an elevation of $387 \mathrm{~m}$ (GPS: $78.3052^{\circ} \mathrm{N}, 16.6012^{\circ} \mathrm{E}$; see Fig. 1 for locality map). The thickness of the bed varies due to uneven compaction of the surrounding shale. The maximum thickness is about $5 \mathrm{~cm}$ but generally the deposit is thinner. The sediments on Marmierfjellet dip slightly towards the east and the full lateral extent of the bonebed deposit into the slope is unknown as permafrost hampered the excavation. At least 5 metres were exposed into the slope during the two field seasons and a total of $35 \mathrm{~m}^{2}$ of bonebed was recovered. The bed is found within the Olenekian (Lower Triassic) sediments of the Vikinghøgda Formation, Vendomdalen Member. There are tectonic disturbances recorded in Central Spitsbergen and in Flowerdalen a part of the Billefjorden Fault Zone cuts through the Mesozoic deposits (Dallmann et al., 2015). In the area where the bonebed is found the lower part of the Vikinghøgda Formation has been downfaulted and Lower Triassic sedimentary rocks rest upon Middle Triassic ones. However, in the immediate vicinity of the bonebed no disturbance of the deposit was apparent (see Fig. 1B for geological map and Fig. 2 for lithological $\log$ ). In Ledalen, about $4 \mathrm{~km}$ northwest of the bonebed locality, deposits of the Vikinghøgda Formation are exposed in steep cliffs (GPS: $78.3302^{\circ} \mathrm{N}, 16.4889^{\circ} \mathrm{E}$; see Fig. 1 for locality map). Here, the upper part of the Lusitaniadalen Member and the entire Vendomdalen Member crop out in a steep section with only the boundary between the two members being inaccessible and obscured by scree material. 


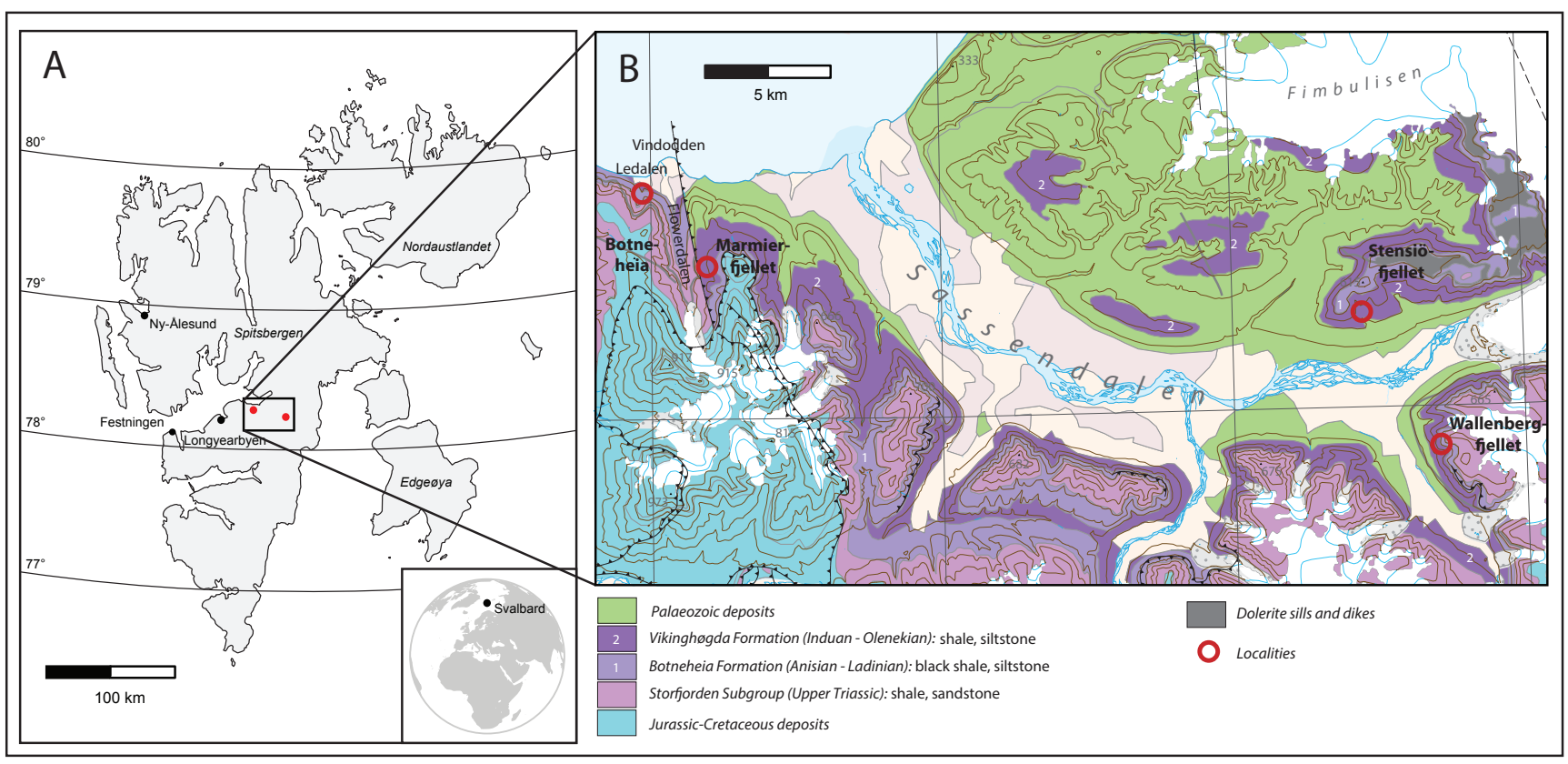

Figure 1. (A) Map of Svalbard with the two main areas explored during field seasons 2014-2017 marked in red. (B) Geological map of the Sassendalen area with the four specific localities mentioned in the text marked in red (modified from Dallmann \& Elvevold, 2015).

\section{Grippia niveau and the Grippia niveau bonebed}

Stensiö (1921) was the first to report a 'real bonebed' of a 'rather local nature' between the Fish niveau and the Lower Saurian niveau on Vikinghøgda and Marmierfjellet. The bonebed was described as sitting in a thin layer $(2 \mathrm{~cm})$ of sandstone and containing a variety of remains from ichthyosaurians, sharks and other marine vertebrates. Stensiö measured the strata on Vikinghøgda and placed the bonebed at $33 \mathrm{~m}$ above the Fish niveau, with large reservations towards measuring accuracy (Stensiö, 1921). The Lower Triassic deposits are not as well preserved on Marmierfjellet as on Vikinghøgda due to faulting (Dallmann et al., 2015). It is therefore likely that the height given by Stensiö is not valid at both localities. The Fish niveau corresponds to the upper part of the Lusitaniadalen Member of the Vikinghøgda Formation. The bonebed should be placed within the overlying Vendomdalen Member (as it is defined by Mørk et al., 1999). At Vikinghøgda, the Vendomdalen Member has a thickness of $94 \mathrm{~m}$ which would place the bonebed about $1 / 3$ up in the member according to Stensiö's measurements. Mørk et al. (1999) have no record of any bonebeds or other significant fossil finds at this level at the locality. The correlation of Stensiös level to ammonoid and palynological zones is therefore highly uncertain. However, Mørk et al. report the finding of the ammonoid Parasibirites cf. elegans 34 $\mathrm{m}$ above the base of the Vendomdalen Member on Milne Edwardsfjellet. This ammonoid is known from the upper Spathian of Siberia and this could indicate a correlation to the Parasibirites grambergi Zone (Mørk et al., 1999).

In 1928, Wiman described the basal ichthyosaur Grippia longirostris from concretions collected as float material, for more details see Hurum et al. 2018. Stensiö had interpreted the material as coming from between the Fish niveau and the Lower Saurian niveau and hereafter the Grippia niveau became a stratigraphic term among palaeontologists. Wiman advanced on the Grippia niveau in 1933 as he reported the findings made by two Swedish expeditions to Svalbard in 1929 and 1930. According to Wiman, the Grippia niveau could be found throughout the southwestern face of (what is now known as) Roslagenfjellet, central Spitsbergen. He claimed the niveau was found consistently at the $33 \mathrm{~m}$ level given by Stensiö (1921) and even marked the level on field photos (Wiman, 1933, figs. $1 \&$ 2). He also reported the finding of ammonoids which were described by Frebold in 1930. Both ammonoids and bones were embedded in yellowweathering concretions (Frebold, 1930). It seems evident that the thin and local bonebed described by Stensiö as a sandy deposit with no record of ammonoids is distinct from the Grippia niveau described by Wiman. Frebold (1930) described and named the ammonoid Svalbardiceras spitzbergense from the Lower Saurian niveau and the Grippia niveau. The specimens assigned to the Grippia niveau were supposedly found alongside bones of Grippia but this is in itself not diagnostic of chronostratigraphic position. The Grippia taxon most likely contains several species covering a considerable time span (Maxwell \& Kear, 2013). Svalbardiceras spitzbergense is indicative of the latest Spathian Keyserlingites subrobustus zone in Svalbard. According to other authors, Svalbardiceras spitzbergense is only found in the upper part of the Vendomdalen Member with first appearances logging about $10 \mathrm{~m}$ below the top (Mørk et al., 1999) though others again place it 15-20 m below the top (Buchan et al., 1965; Hounslow et al., 2008). Frebold himself places the Grippia niveau about $30 \mathrm{~m}$ 


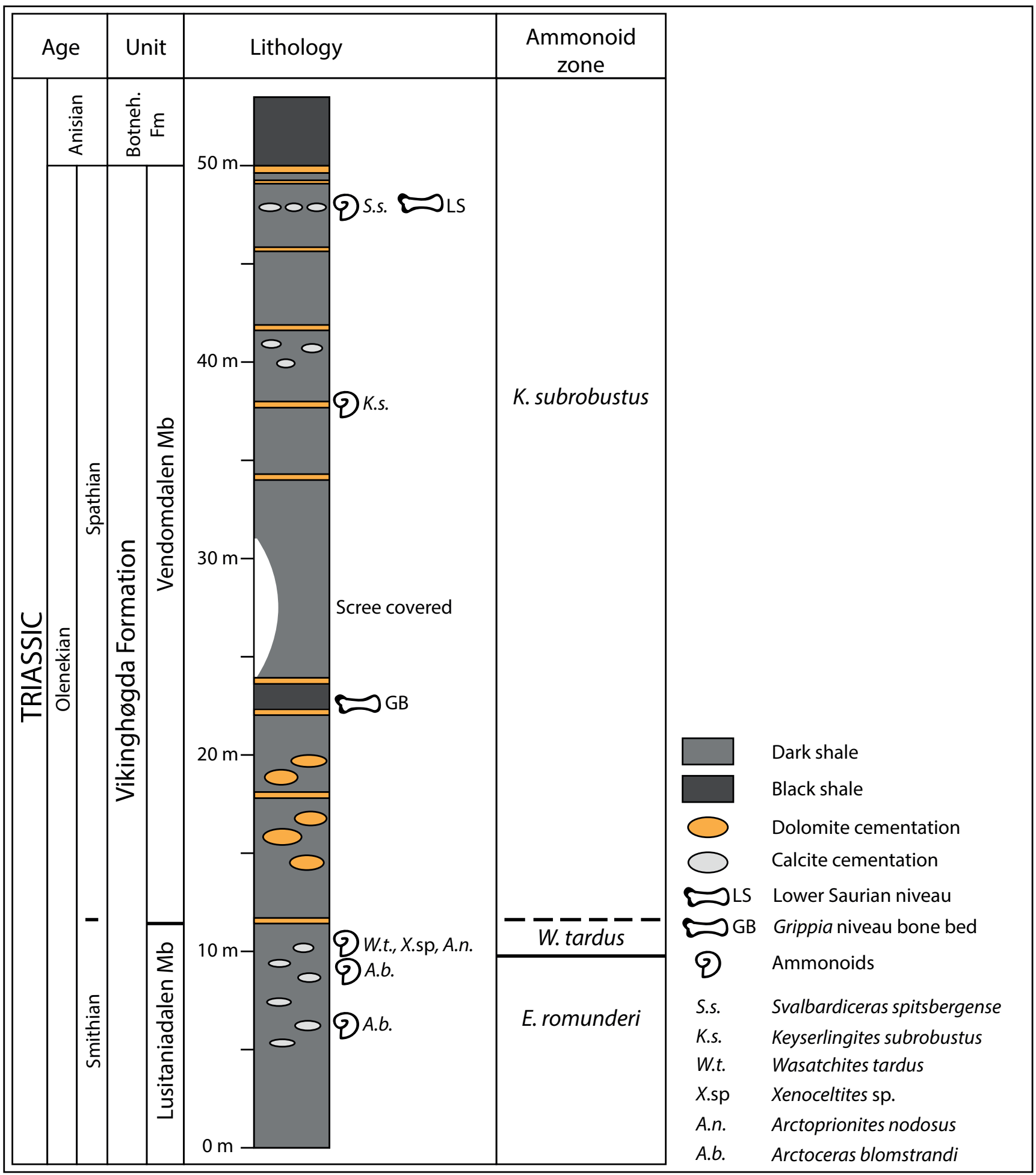

Figure 2. Lithological log of the Olenekian section on Marmierfjellet $\left(78.3052^{\circ} \mathrm{N}, 16.6012^{\circ} \mathrm{E}\right)$.

below the top which correlates well with the bonebed on Marmierfjellet. However, Frebold does not appear to have had any first-hand knowledge of the strata in Svalbard and is rather vague on the vertical extent of the Grippia niveau. As no other authors have reported Svalbardiceras spitzbergense as low as Frebold, it seems likely that he is in fact treating most of the Vendomdalen Member as the Grippia niveau. All-in-all, it remains unclear whether the Grippia niveau is a specific single concretion horizon or an interval of shale and several concretion horizons. Succeeding authors have applied the term 'Grippia niveau' to everything in between the Fish niveau and the Lower Saurian niveau, grouping most of the Spathian fauna into one faunal unit (Buchan et al., 1965; Maxwell \& Kear, 2013). 


\section{Material and methods}

Logging, fossil collection and sampling for geochemistry was done on Marmierfjellet and in Ledalen during three consecutive field seasons (2014-2016). Logs are shown in Figs. 2, 3 \& 4. All material is deposited in the palaeontological collections of the Natural History Museum, University of Oslo (PMO), and figured material catalogued accordingly.

In 2014 we logged the Vikinghøgda Formation on Marmierfjellet (Fig. 2) and in Ledalen. In 2015 the Grippia niveau bonebed on Marmierfjellet was partly excavated and the material was washed and sieved at the Natural History Museum, Oslo. New fieldwork was carried out in 2016 when the bonebed was excavated further and the quarry was logged and sampled for geochemistry (Fig. 4). Logging, fossil collection and sampling for geochemistry were done in Ledalen the same year. The work was done on a section on the eastern side of the stream in the ravine (Fig. 3).

Sedimentary samples collected in 2016 were analysed for carbon isotope ratios, TOC values and contents of selected elements. Samples were taken in Ledalen every second metre from within the Lusitaniadalen Member $(0 \mathrm{~m}$ corresponds to the water level of the stream) to a stratigraphic level of $24 \mathrm{~m}$ where the shoulder of the cliff became inaccessible. Sampling continued a short way farther up in the lowermost Vendomdalen Member $(0 \mathrm{~m}$ corresponds to a plateau in the cliff face on top of a horizon of large yellow-weathering nodules). The last sample was taken $37 \mathrm{~m}$ above the plateau on the underside of the bench marking the boundary to the Botneheia Formation. Lithological and chemostratigraphic logs are presented for the strata exposed in Ledalen and in the Grippia niveau bonebed quarry (Figs. $3 \& 4$ ). The data are linked with the lithological log from Marmierfjellet and compared to Lower Triassic data presented by others.

\section{Geochemistry}

$\delta^{13} \mathrm{C}$ and TOC analyses were carried out by the Institute for Energy Technology, Kjeller (IFE) using the following method. Samples were crushed and homogenised in an agate mortar prior to analysis. Each sample was added $2 \mathrm{ml} 2 \mathrm{M} \mathrm{HCl}$ pr. $100 \mathrm{mg}$ sample and placed at room temperature overnight. Samples were cleaned with pure water and dried in an oven for more than 12 hours at 80 ${ }^{\circ} \mathrm{C}$. From each sample $10 \mathrm{mg}$ of material was transferred to a $4 \times 6 \mathrm{~mm}$ tin capsule. The combustion of the samples in the presence of $\mathrm{O}_{2}$ and $\mathrm{Cr}_{2} \mathrm{O}_{3}$ at $1700^{\circ} \mathrm{C}$ was done in a Eurovector EA3028 element analyser. Excess of $\mathrm{O}_{2}$ was reacted with $\mathrm{Cu}$ in an oven at $650^{\circ} \mathrm{C} . \mathrm{H}_{2} \mathrm{O}$ was removed in a chemical trap of $\mathrm{Mg}\left(\mathrm{ClO}_{4}\right)_{2}$ before the separation of $\mathrm{CO}_{2}$ from other compounds on a $2 \mathrm{~m}$
Poraplot Q GC column. $\mathrm{CO}_{2}$ was transferred on-line to a Horizon Isotope Ratio Mass Spectrometer (IRMS) from $\mathrm{Nu}$-Instruments, for determination of $\delta^{13} \mathrm{C}$ and quantification of $\mathrm{C}$. The amount of $\mathrm{C}$ was calculated on the basis of mass spectrometer area of mass $28\left(\mathrm{~N}_{2}\right)$ and mass $44\left(\mathrm{CO}_{2}\right)$. All results were plotted on a calibration line calculated from analysis of international reference materials analysed in each sequence. For quality control, B 2151 and/or B 2153, high and low organic content soil standards from Elemental Microanalysis, England, were analysed in each sequence.

$\mathrm{XRF}$ analysis was done in-house. A piece of rock was selected from each sample, washed and analysed directly using handheld X-ray fluorescence spectroscopy (HHXRF). The instrument used was a Thermo Scientific Niton XL3t GOLDD+ with an aperture of $8 \mathrm{~mm}$. Integration time was $120 \mathrm{~s}$ in the 'Mining $\mathrm{Cu} / \mathrm{Zn}$ ' mode. After every five samples, a calibration measurement was taken on a pressed powder pellet of the USGS Columbia River Basalt BCR-2 standard, diluted to four parts powder and one part binder. The diluted standard has a certified V concentration of $416 \pm 14(1 \mathrm{SD}) \mathrm{ppm}$. No drift in the $\mathrm{V}$ measurement of the standard was observed, and the variance was relatively small, with average $\mathrm{V}$ concentration $420 \pm 24(1 \mathrm{SD}) \mathrm{ppm}, \mathrm{N}=10$, i.e., within the error of the certified standard value. Still, we regard the $\mathrm{V}$ curve obtained as semi-quantitative.

\section{Conodonts}

Several kilograms of fossiliferous shale material were retrieved from the Grippia niveau bonebed in 2015 and 2016. This material has been used for various purposes, and some of it has been wet sieved in various fractions, from $63 \mu \mathrm{m}$ upwards. No further chemical treatment (like acetic acid) was applied. The fraction 63-250 $\mu \mathrm{m}$ was heavy-liquid separated using bromoform, and conodont elements were picked from the heavy residue and photographed on SEM. Many elements are fairly large, more than $250 \mu \mathrm{m}$ long, and future processing will also consider the $250-500 \mu \mathrm{m}$ fraction.

\section{Results}

The slope on Marmierfjellet holding the bonebed has a low angle and is to a high degree covered by loose material. This made logging difficult and geochemical sampling impossible within the time span of our expeditions. The lithological $\log$ from Marmierfjellet is supported by ammonoid observations but these were infrequent and generally difficult to identify. The bonebed is placed with certainty in the Vendomdalen Member of the Vikinghøgda Formation as it lies between yellow-weathering benches characteristic of the member. However, the member is 


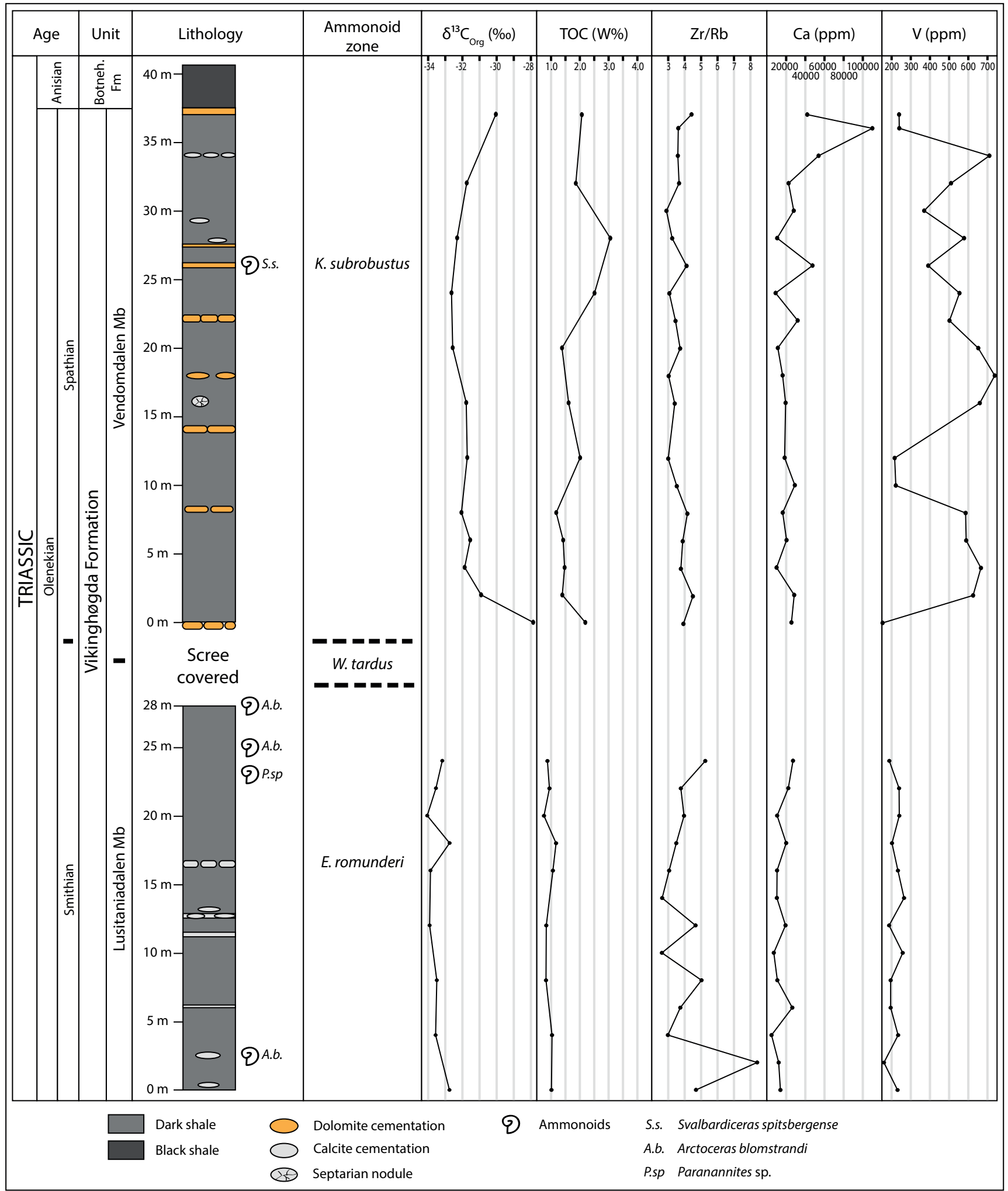

Figure 3. Lithological and geochemical log of the Olenekian section in Ledalen $\left(78.3302^{\circ} \mathrm{N}, 16.4889^{\circ} \mathrm{E}\right)$. 


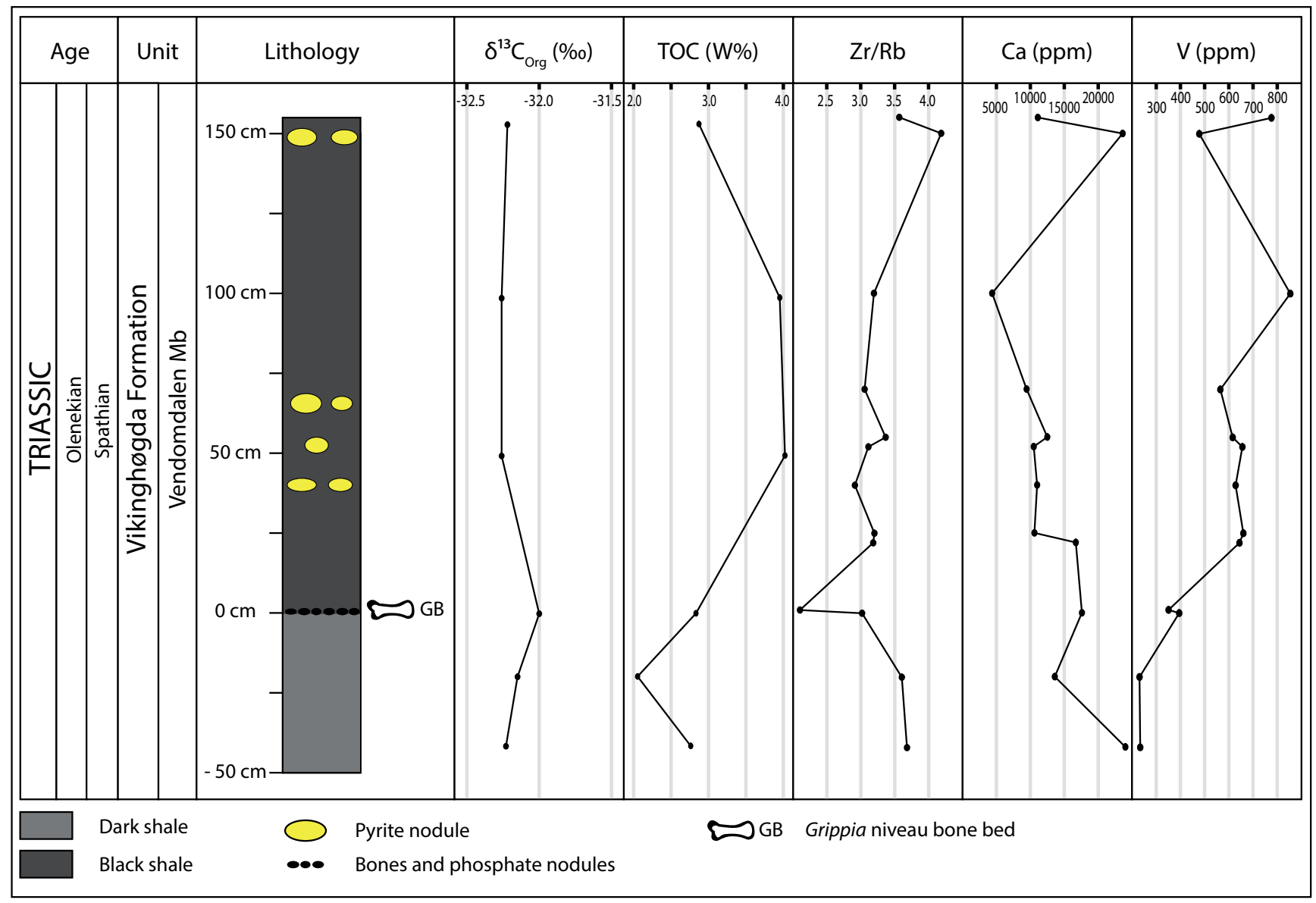

Figure 4. Lithological and geochemical log of the Grippia niveau bonebed.

thinner here than in other localities making correlation between localities difficult. It is uncertain if the Olenekian sediments in Flowerdalen have been eroded immediately after deposition or if subsequent faulting has removed part of the succession. It is also possible that sedimentation rates were locally low in the palaeo-sea. For this reason we logged and sampled the nearby locality in Ledalen for supporting stratigraphic data. A few of the cemented horizons in the Vikinghøgda Formation are easily recognised at separate localities but generally the horizons cannot be followed over large distances. The yellow-weathering, cemented, sandy horizon marking the boundary between the Vikinghøgda Formation and the Botneheia Formation is recognised throughout Central Spitsbergen though it varies in thickness. Between Marmierfjellet and Ledalen we also recognise a level of grey calcareous nodules immediately below the top of the formation. At levels of about $12 \mathrm{~m}$ and $16 \mathrm{~m}$ below the top, comparable yellow-weathering cemented horizons are seen at both localities. Otherwise, it is not possible to say for certain which levels correlate based on lithology alone. No fossiliferous level comparable to the bonebed on Marmierfjellet is observed in Ledalen.

Two main questions arise. How complete are the Olenekian sedimentary successions on Marmierfjellet and in Ledalen compared to other localities? How high in the Vendomdalen Member is the bonebed located in relation to biozones and relative and absolute age?

\section{Olenekian biostratigraphy}

Ammonoids are the most common macrofossils used in biostratigraphy due to their rapid evolution and high speciation rates and generally wide regional distribution. However, in Lower Triassic deposits on Svalbard there are large gaps in the ammonoid record. Where other regions can be dated by numerous zones and subzones through most of the Olenekian, the Svalbard area suffers from the lack of preserved index fossils. On Marmierfjellet three ammonoid zones are identified (see Fig. 2). In the Lusitaniadalen Member the Smithian Euflemingites romunderi Zone is recognised from the associated Arctoceras blomstrandi which has a last occurrence about $2.5 \mathrm{~m}$ below the lithostratigraphic boundary to the Vendomdalen Member. Wasatchites tardus, Xenoceltites sp. and Arctoprionites nodosus are indicative of the late Smithian Wasatchites tardus Zone. The Wasatchites tardus zone has an uncertain range on Svalbard but is restricted to a couple of metres across the lithological boundary between the Vendomdalen and 
the Lusitaniadalen members (Mørk et al., 1999). In the Vendomdalen Member on Marmierfjellet only the late Spathian Keyserlingites subrobustus Zone is recognised in the upper part from occurrences of the index species and the associated Svalbardiceras spitsbergense. The early Spathian Bajarunia euomphala Zone and the early to mid Spathian Parasibirites grambergi Zone have been recognised in the lower half of the Vendomdalen Member from isolated finds at other localities (Mørk et al., 1999). On Marmierfjellet, neither zone could be confirmed. In Ledalen, the Wasatchites tardus Zone cannot be confirmed whereas the Euflemingites romunderi Zone is recognised from Arctoceras blomstrandi specimens that are found immediately below the scree-covered part (see Fig. 3). The Keyserlingites subrobustus Zone is only recognised from a tentative identification of a Svalbardiceras spitsbergense specimen about $11 \mathrm{~m}$ below the top of the Vendomdalen Member. In Ledalen, Paranannites sp. is additionally identified in support of the Euflemingites romunderi Zone.

Conodonts play an important role in the construction of a biostratigraphic scheme for the Triassic. They fill in gaps where ammonoids are rare or absent as they are subject to different preservational biases. However, in the Lower Triassic there are gaps in the conodont zonation. A gap in the Spathian succession is partly caused by a lack of carbonates which leads to inconsistent sampling and partly caused by a faunal crisis in the late Smithian. As in other time units, Triassic conodonts show some degree of provincialism and facies dependency. For the Triassic, a parallel zonation of Hindeodus-Isarcicella vs gondolellid biofacies has been erected (Nicoll et al., 2002; Orchard, 2010). Species of Hindeodus, including the index species $H$. parvus for the base of the Triassic, are extremely rare in the Candian Arctic (Henderson \& Baud, 1997; Orchard, 2008) and are unknown from the Triassic of Svalbard (Nakrem et al., 2008). Gondolellids are, however, common in both areas and have proven useful in biostratigraphic zonation.

\section{The Olenekian succession in Ledalen}

Wignall et al. (2016) have suggested that no uppermost Spathian deposits are present at Vindodden (most likely based on a locality adjacent to Ledalen) based on organic $\delta^{13} \mathrm{C}$ data and conodont occurrences. The $\delta^{13} \mathrm{C}_{\text {org }}$ curve given by Wignall et al. does not, however, resemble our data from the locality (see Fig. 3). Our curve resembles the one Wignall et al. (2016) presented from Festningen ( $\sim 0 \mathrm{~km}$ to the $\mathrm{W}-\mathrm{SW}$ of Ledalen). The Lower Triassic deposits at Festningen are assigned to the Vardebukta and Tvillingodden formations which are synchronous with the Vikinghøgda Formation (Mørk et al., 1999) but deposited in a more coastal setting. Furthermore, our data resemble those of Galfetti et al. (2007) for the Vikinghøgda Formation on Dicksonfjellet (= Kongressfjellet) $\sim 40 \mathrm{~km}$ to the northwest of Ledalen and that of Grasby et al. (2013) from the Olenekian marine deposits of the Sverdrup Basin, Arctic Canada. In our new data from Ledalen we see low $\delta^{13} \mathrm{C}_{\text {org }}$ values in the Lusitaniadalen Member (-33 to $-34 \%$ ), and a positive excursion around the boundary to the Vendomdalen Member (maximum of about -28\%o). In the Vendomdalen Member, values decrease again and remain fairly stable at a higher level than in the Lusitaniadalen Member (around -32\%o). Values increase again towards the top of the member (maximum value of about $-30 \%$ ) as is also seen from other localities (Grasby et al., 2013; Wignall et al., 2016) indicating an inclusion of approximately the same time interval. We have too few data points to determine if any part of the Olenekian is missing in Flowerdalen or if the sedimentation rate was in fact lower here than elsewhere throughout the period. At the lithological boundary between the Lusitaniadalen and Vendomdalen members we lack data points due to scree and difficult accessibility.

\section{The Smithian-Spathian boundary in Ledalen}

The Smithian and Spathian substages were erected by Tozer (1965) and are today in general use. The subdivision of the Olenekian, however, is still informal (Ogg et al., 2014). In the Boreal realm the Smithian-Spathian boundary is so far defined as the upper limit of the Wasatchites tardus Zone (Ogg et al., 2014). In Ledalen, we could not identify any individuals of $W$. tardus. We found Arctoceras blomstrandi at the very top of what is exposed of the Lusitaniadalen Member. A. blomstrandi is indicative of the Euflemingites romunderi Zone in Svalbard and is mutually exclusive with Wasatchites tardus of the overlying zone (Weitschat \& Dagys, 1989). The Wasatchites tardus Zone is generally very thin in Svalbard sections (e.g., Mørk et al., 1999) and in Ledalen it most likely lies within the covered part. It has become normal practice to identify the Smithian-Spathian boundary from the major global positive $\delta^{13} \mathrm{C}$ excursion which coincides with a biotic crisis and faunal turnover. The isotope excursion is evident from both organic and carbonate carbon from various localities. However, there is so far much inconsistency in how authors place the Smithian-Spathian boundary in relation to the excursion. Some place the boundary at the onset of the positive excursion (e.g., Wignall et al., 2016), others in the middle (e.g., Galfetti et al., 2007), others again place it at the peak (e.g., Grasby et al., 2013; Foster et al., 2017) or even without any internal consistency (e.g., Grasby et al., 2016). In Ledalen, the onset of the $\delta^{13} \mathrm{C}$ excursion (and possibly also the highest peak) lies in the covered section, thus obstructing an accurate placement of the SmithianSpathian boundary.

\section{Grippia niveau bonebed chemostratigraphy}

The Grippia niveau bonebed on Marmierfjellet is situated $11 \mathrm{~m}$ above the top of the Lusitaniadalen Member and 
$27.5 \mathrm{~m}$ below the base of the Botneheia Formation. This places it about $1 / 3$ up in the Vendomdalen Member, similar to the bonebed described by Stensiö (1921) from Vikinghøgda and Marmierfjellet. The atypical thickness of the Vikinghøgda Formation in Flowerdalen raises the problem of placing the bonebed correctly in the stratigraphic scheme. The bonebed itself is fairly thin, unconsolidated, phosphate rich and carbonate depleted. It overlies grey shales and is followed by black shales containing pyrite nodules (see Fig. 4). It could represent a condensed horizon from an interval of low sedimentation rates or result from erosion, reworking and resedimentation - both possibly in the context of a sea level rise. The taphonomy of the bonebed will be investigated in a future publication.

The $\delta^{13} \mathrm{C}_{\text {org }}$ values of the Grippia niveau bonebed and adjacent sediments lie between $-32.26 \%$ and $-32.0 \%$. This places the bonebed above the positive excursion at the Smithian-Spathian boundary but below the positive $\delta^{13} \mathrm{C}$ shift towards the top of the Spathian.

TOC data from Ledalen have a somewhat similar trend as the $\delta^{13} \mathrm{C}$ values. The Lusitaniadalen Member holds low stable values of around $1 \mathrm{wt} . \%$. In the Vendomdalen Member values are generally higher (up to 3 wt.\%) and more variable. TOC values from the Grippia niveau bonebed vary within an interval of $70 \mathrm{~cm}$ from $2 \mathrm{wt} . \%$ below the bonebed to $4 \mathrm{wt} . \%$ above. At $150 \mathrm{~cm}$ above the bonebed values have decreased to $3 \mathrm{wt} . \%$ again, making the signal less likely to be caught with the sampling interval done in Ledalen. It is also a possibility that the high value of $4 \mathrm{wt} . \%$ is seen only at Marmierfjellet in relation to the bonebed.

Zirconium-rubidium ratios are used as a relative indicator of grain size. High ratios are indicative of relatively more sandy sediments because zirconium is more abundant in sand grains while rubidium is more abundant in clays (Dypvik \& Harris, 2001). In Ledalen, we see fluctuating ratios of $\mathrm{Zr} / \mathrm{Rb}$ in the Lusitaniadalen Member and lower and more stable ratios in the Vendomdalen Member. This corresponds with earlier interpretations of the Vikinghøgda Formation as having been deposited under successively deeper marine conditions (Mørk et al., 1999). $\mathrm{Zr} / \mathrm{Rb}$ ratios from the Grippia niveau bonebed are low and support the placement within the Vendomdalen Member.

Calcium values are expected to oscillate strongly throughout a section with numerous calcareous nodule horizons and benches. In Ledalen, we see fairly stable and relatively low values in the Lusitaniadalen Member and lower half of the Vendomdalen Member. The upper $15 \mathrm{~m}$ of the Vendomdalen Member is characterised by highly fluctuating Ca values ranging from less than 20,000 ppm to more than 100,000 ppm. Ca values across the Grippia niveau bonebed are very low except for in one sample from the bonebed itself where fossil bone material gave a value of 107,200 ppm (data point left out of log in Fig. 4). Calcium values are inconclusive but point to a placement of the bonebed in the lower c. $20 \mathrm{~m}$ of the Vendomdalen Member when comparing to the section in Ledalen.

Vanadium values in marine sediments can be indicative of oxygenation at the sediment-water interface (Calvert \& Pedersen, 1993). Large values are not taken as direct numerical evidence of anoxia but relative shifts between low and high values indicate shifts between more and less oxic conditions. In Ledalen, we find low and stable $\mathrm{V}$ values in the Lusitaniadalen Member contrasting with high and fluctuating values in the Vendomdalen Member. The area seems to have experienced stable, welloxygenated, bottom conditions in the middle Smithian contrasting with unstable conditions in the Spathian with long episodes of anoxia/hypoxia. As we were not able to sample the sediments representing the Wasatchites tardus Zone, it is impossible to say if the first anoxic event occurred in the late Smithian or early Spathian. The first event recovered from our data dates above the Smithian-Spathian boundary as it occurs together with the negative shift in the $\delta^{13} \mathrm{C}_{\text {org }}$ values. From $0 \mathrm{~m}$ to $2 \mathrm{~m}$ above the scree-covered section in Ledalen, $\mathrm{V}$ values increase by $472 \mathrm{ppm}$. Values remain high up to $8 \mathrm{~m}$ above the scree-covered section. From $10 \mathrm{~m}$ to $12 \mathrm{~m}, \mathrm{~V}$ values are as low as in the Lusitaniadalen Member indicating an interval of oxygenated conditions at the sediment-water interface. From $12 \mathrm{~m}$ to $16 \mathrm{~m}$, the $\mathrm{V}$ values increase from $216 \mathrm{ppm}$ to $660 \mathrm{ppm}$ and at $18 \mathrm{~m}$ they reach a maximum value of $738 \mathrm{ppm}$. A sudden shift in $\mathrm{V}$ values is also seen across the Grippia niveau bonebed on Marmierfjellet where $\mathrm{V}$ increases from $231 \mathrm{ppm}$ to $854 \mathrm{ppm}$ within an interval of $120 \mathrm{~cm}$. This is the best indication that the Grippia niveau bonebed correlates to a level between 12 $\mathrm{m}$ and $16 \mathrm{~m}$ in our section from Ledalen. The shift in vanadium values correlates with increasing TOC values across the bonebed and is a strong indication of the onset of a period of anoxic conditions on the seafloor. It is possible that the anoxic conditions formed during a relatively rapid sea level rise and that the bonebed formed as a condensed horizon. Other sources of anoxia could be a stratification of the water masses resulting in poor circulation of the bottom waters or high levels of organic productivity draining the available oxygen. Future research will attempt to place the Grippia niveau bonebed in a regional environmental context. The vanadium signal from Ledalen seems to be a reliable primary signal as similar curves have been obtained from Stensiöfjellet and Wallenbergfjellet in 2017 (Fig. 5). Stensiöfjellet and Wallenbergfjellet lie on opposite sides of Sassendalen about $30 \mathrm{~km}$ to the E-SE of Ledalen. The successions are not of equal thickness at the three localities but signals correlate well with stratigraphic boundaries. Comparing the $\mathrm{V}$ curve from Ledalen to the $\mathrm{V}$ curves from Stensiöfjellet and Wallenbergfjellet makes it evident that the Lusitaniadalen Member in Central Spitsbergen is characterised by low stable values compared to the Vendomdalen Member. On Stensiöfjellet, the shift to 


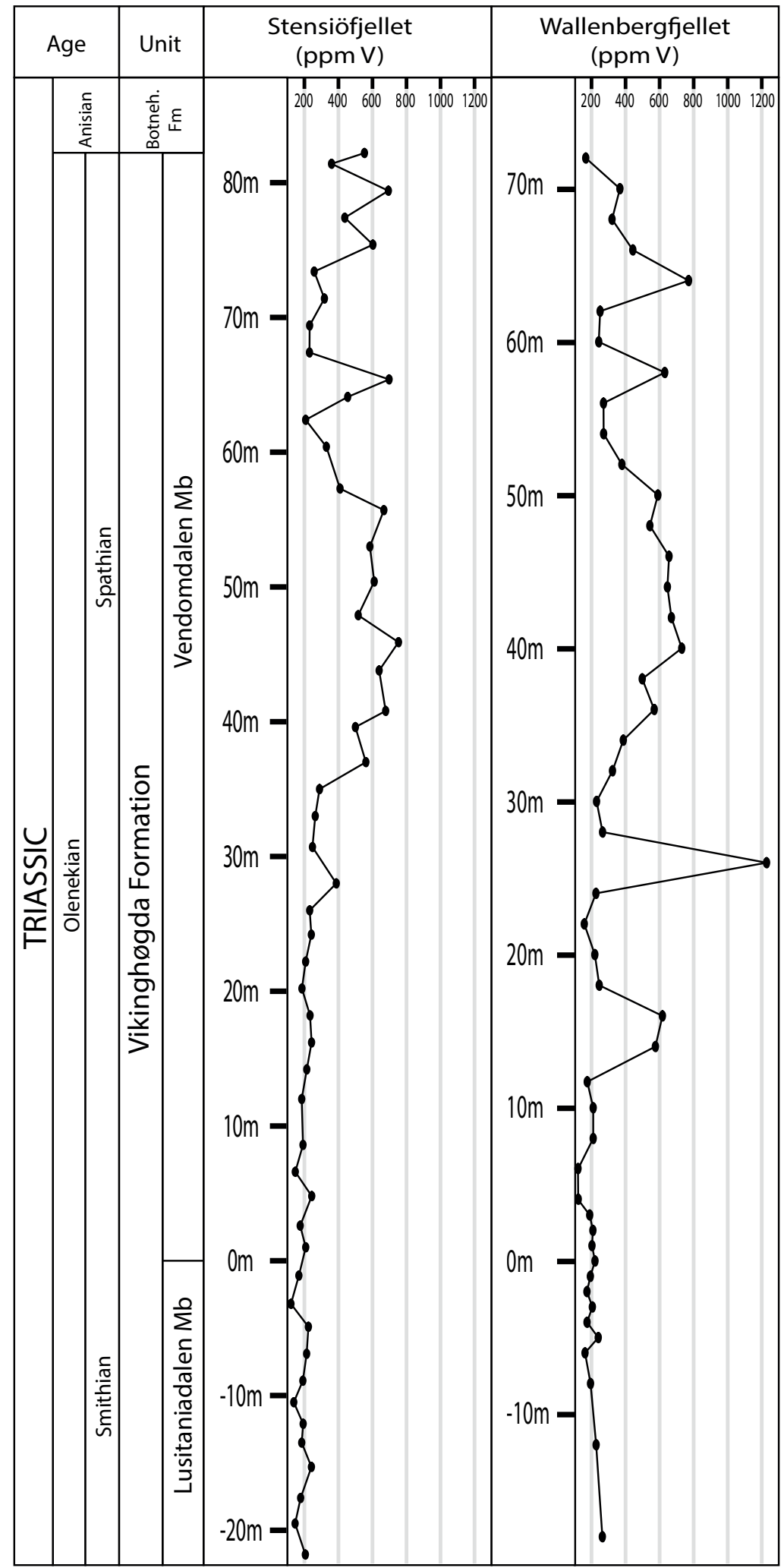

Figure 5. Vanadium curves from the Olenekian sections on Wallenbergfjellet and Stensiöfjellet.

values of c. $600 \mathrm{ppm}$ is not seen until about 37 metres above the base of the Vendomdalen Member indicating more consistently oxygenated bottom conditions at this locality. On Wallenbergfjellet, high V values appear about
14 metres above the base of the Vendomdalen Member indicating an early shift to anoxic conditions about $1 / 5$ up in the member. 


\section{Grippia niveau bonebed biostratigraphy}

No ammonoid fossils were found within the Grippia niveau bonebed or in the shale deposits immediately above and below. The bonebed cannot be directly correlated to any ammonoid zone. Based on the lithoand chemostratigraphic placement of the bonebed, it is possible to compare with other sections in Svalbard and the zones identified in these (Mørk et al., 1999; Hounslow et al., 2008; Vigran et al., 2014). The Bajarunia euomphala Zone and the Parasibirites grambergi Zone are equally likely whereas placement in the Keyserlingites subrobustus Zone is very unlikely though it cannot be completely excluded. The Bajarunia euomphala Zone is of early Spathian age while the Parasibirites grambergi Zone is of early to middle Spathian age (Jenks et al., 2015).

While ammonoids are completely absent, conodont elements were found in abundance in the heavy fraction of the sedimentary material gathered from the Grippia niveau bonebed. However, the preservation of the elements is rather poor. Some elements are probably reworked from older beds and some were physically damaged during sieving or from long-term erosional processes. More bonebed sediment is being processed to obtain a more representative conodont material for future identification. We have not been able to identify the probably reworked material at this point. Some specimens from the initial material are nevertheless preserved adequately for preliminary identification (Fig. 6). Not considering probably reworked specimens, the faunule is highly dominated by gondolellids. Identification to species level is uncertain, but some elements resemble Neogondolella n. sp. C, D, and E from the Spathian in Orchard (2007) and Neogondolella n. sp. K = Neogondolella? joannae Orchard \& Zonneveld (2009) (M.J. Orchard, pers. comm., 2017). Thus, the preliminary study of conodonts from the Grippia niveau bonebed has revealed the presence of probably Spathian taxa in a stratigraphic level that previously has been reported devoid of conodonts (Nakrem et al., 2008). Wignall et al. (2016) reported a less diverse but otherwise comparable conodont faunule from the Spathian part of the Vikinghøgda Formation at Vindodden (locality in the vicinity of Ledalen). Here, however, the stratigraphic levels were not precisely specified (Wignall et al., 2016). The lower part of the Spathian of the Canadian Arctic is likewise poor in conodont occurrences (Orchard, 2008). The dominance of segminiplanate species and an absence of segminate species are as expected (Nicoll et al., 2002) in the low-energy, distal, depositional setting of the Vendomdalen Member, the distal "Shale Facies" of Wignall et al. (2016, fig. 10). An extensive identification and description of the Grippia niveau bonebed conodonts is under preparation.

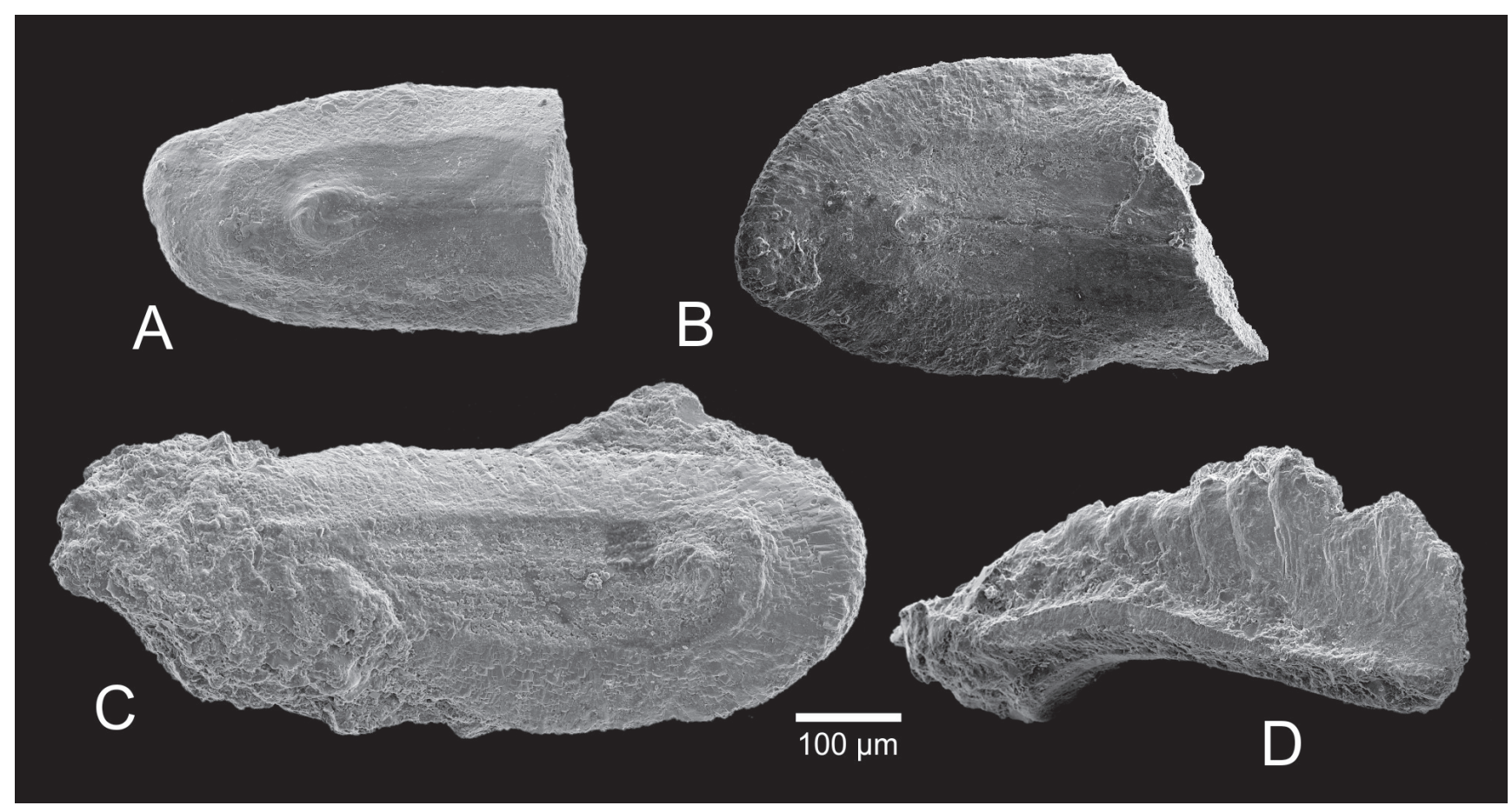

Figure 6. SEM images of conodonts from the Grippia niveau bonebed. (A-C) cf. Neogondolella n. sp. C, D and E of Orchard (2007) (lower view). (A) PMO 226.934/5; (B) PMO 226.934/20; (C) PMO 226.934/6. (D) cf. Neogondolella $n$. sp. K of Orchard (2007) = Neogondolella? joannae of Orchard \& Zonneveld (2009) (lateral view). PMO 226.934/24. 


\section{Conclusions}

We provide chemostratigraphic data and age constraints on a Spathian (Lower Triassic) bonebed located on Marmierfjellet in Flowerdalen, Central Spitsbergen. The bonebed contains bones and teeth from marine vertebrates along with conodont elements. To put the Spathian fauna of Svalbard into a regional and global context, the bonebed needs to be placed in a stratigraphic and chronologic framework. The bonebed is situated in the Grippia niveau, which is an old term for a fossiliferous interval found between the Fish niveau and the Lower Saurian niveau. All three terms have been used without much stratigraphic control. The Grippia niveau has been used at times for everything between the Fish niveau and the Lower Saurian niveau, thus spanning the Spathian. The bonebed treated here is likely to be identical to the bonebed first described by Stensiö in 1921 which led to the erection of the Grippia niveau by Wiman. The bonebed has now been excavated through two field seasons (2015-2016) and the material is stored at the Natural History Museum, Oslo. The bonebed is up to 5 $\mathrm{cm}$ thick and covers an area of at least $35 \mathrm{~m}^{2}$. The bed is found in the Vendomdalen Member of the Vikinghøgda Formation. On Marmierfjellet, the Vikinghøgda Formation is thinner than elsewhere and the precise stratigraphic placement of the bonebed is uncertain. Through chemostratigraphic correlation with localities in Ledalen and in Sassendalen, it is established that the bonebed belongs to the lower part of the Vendomdalen Member and most likely sits about 1/3 up in the member. Based on the stratigraphic level, the bonebed correlates to the Bajarunia euomphala Zone or Parasibirites grambergi Zone which makes it either early or early/middle Spathian in age. Non-reworked conodont elements from the bonebed support a Spathian age. Vanadium data and TOC content from the bonebed indicate that it was formed under increasing anoxic conditions.

Acknowledgements. All necessary permits were obtained from the Governor of Svalbard for the excavations and fieldwork 2014-2016. Permits no. RiS 6725, 2013/1222-2; RiS 10227, 2015/00326-2; RiS 10539, 2015/00326-5. Thanks are given to Spitsbergen Travel, National Geographic, Bayerngas Norge, Tullow Oil and CGG for financing field work 2014-16. Personal thanks are given to the Spitsbergen Mesozoic Research Group (Jørn, Aubrey, Achim, Tanja, Bjørn, Øyvind, Stig, Victoria, Tommy, Patrick, Charlotte, Lene, Ole Frederik, Christina, Inghild, Lena, Magne). Christina Ekeheien and Janne Bratvold washed and sieved the bonebed material excavated in 2015. Michael J. Orchard is thanked for providing valuable comments on the identification of the conodonts. Geochemical data from Stensiöfjellet and Wallenbergfjellet were acquired via funding from the Swiss National Science Foundation Project No. 160055 and in close collaboration with Hugo Bucher, Elke Schneebeli-Hermann and Franz-Josef Lindemann. This manuscript benefitted from the constructive reviews by Hugo Bucher and Atle Mørk.

\section{References}

Bratvold, J., Delsett, L.L. \& Hurum, J.H. 2018: Chondrichthyans from the Grippia bonebed (Early Triassic) of Marmierfjellet, Spitsbergen. Norwegian Journal of Geology 98, 189-217. https://dx.doi.org/10.17850/njg98-2-03.

Brayard, A., Krumenacker, L.J., Botting, J.P., Jenks, J.F., Bylund, K.G., Fara, E., Vennin, E., Olivier, N., Goudemand, N., Saucède, T., Charbonnier, S., Romano, C., Doguzhaeva, L., Thuy, B., Hautmann, M., Stephen, D.A., Thomazo, C. \& Escarguel, G. 2017: Unexpected Early Triassic marine ecosystem and the rise of the Modern evolutionary fauna. Science Advances 3. https://doi.org/10.1126/sciadv.1602159.

Buchan, S.H., Challinor, A., Harland, W.B. \& Parker, J.R. 1965: The Triassic stratigraphy of Svalbard. Norsk Polarinstitutt skrifter 135, 97 pp.

Calvert, S.E. \& Pedersen, T.F. 1993: Geochemistry of Recent oxic and anoxic marine sediments: Implications for the geological record. Marine Geology 113, 67-88. https://doi.org/10.1016/0025-3227(93)90150-T.

Chen, Z.Q. \& Benton, M.J. 2012: The timing and pattern of biotic recovery following the end-Permian mass extinction. Nature Geoscience 5, 375-383. https://doi.org/10.1038/ngeo1475.

Dallmann, W.K. \& Elvevold, S. 2015: Bedrock Geology. In Dallmann, W.K. (ed.): Geoscience Atlas of Svalbard, Norsk Polarinstitutt, Tromsø, Report Series 148, pp. 133-173.

Dallman, W.K., Elvevold, S., Majka, J. \& Piepjohn, K. 2015: Tectonics and tectonothermal events. In Dallmann, W.K. (ed.): Geoscience Atlas of Svalbard, Norsk Polarinstitutt, Tromsø, Report Series 148, pp. 175-223.

Dypvik, H. \& Harris, N.B. 2001: Geochemical facies analysis of finegrained siliciclastics using $\mathrm{Th} / \mathrm{U}, \mathrm{Zr} / \mathrm{Rb}$ and $(\mathrm{Zr}+\mathrm{Rb}) / \mathrm{Sr}$ ratios. Chemical Geology 181, 131-146. https://doi.org/10.1016/S0009-2541(01)00278-9.

Ekeheien, C.P., Delsett, L.L., Roberts, A.J. \& Hurum, J.H. 2018: Preliminary report on ichthyopterygian elements from the Early Triassic (Spathian) of Spitsbergen. Norwegian Journal of Geology 98, 219-237. https://dx.doi.org/10.17850/njg98-2-07.

Engelschiøn, V.S., Delsett, L.L., Roberts, A.J. \& Hurum, J.H. 2018: Large-sized ichthyosaurs from the Lower Saurian niveau of the Vikinghøgda Formation (Early Triassic), Marmierfjellet, Spitsbergen. Norwegian Journal of Geology 98, 239-265. https://dx.doi.org/10.17850/njg98-2-05.

Foster, W.J., Danise, S., Price, G.D. \& Twitchett, R.J. 2017: Subsequent biotic crises delayed marine recovery following the late Permian mass extinction event in northern Italy. PLoS ONE 12, 24 pp.

Frebold, H. 1930: Die Alterstellung des Fischhorizontes, des Grippianiveaus and des unteren Saurierhorizontes in Spitzbergen. Skrifter om Svalbard og Ishavet 28, $36 \mathrm{pp}$.

Galfetti, T., Hochuli, P.A., Brayard, A., Bucher, H., Weissert, H. \& Vigran, J.O. 2007: Smithian-Spathian boundary event: Evidence for global climatic change in the wake of the end-Permian biotic crisis. Geology 35, 291-294. https://doi.org/10.1130/G23117A.1.

Grasby, S.E., Beauchamp, B., Embry, A. \& Sanei, H. 2013: Recurrent Early Triassic ocean anoxia. Geology 41, 175-178. https://doi.org/10.1130/G33599.1.

Grasby, S.E., Beauchamp, B., Bond, D.P.G., Wignall, P.B. \& Sanei, H. 2016: Mercury anomalies associated with three extinction events (Capitanian Crisis, Latest Permian Extinction and the Smithian/ Spathian Extinction) in NW Pangea. Geological Magazine 153, 285-297. https://doi.org/10.1017/S0016756815000436.

Henderson, C.M. \& Baud, A. 1997: Correlation of the Permian-Triassic boundary in Arctic Canada and comparison with Meishan, China. Proceedings of the 30th International Geological Congress 11, 143-152. 
Hounslow, M.W., Hu, M., Mørk, A., Weitschat, W., Vigran, J.O., Karloukovski, V. \& Orchard, M.J. 2008: Intercalibration of Boreal and Tethyan time scales: the magnetobiostratigraphy of the Middle Triassic and the latest Early Triassic from Spitsbergen, Arctic Norway. Polar Research 27, 469-490. https://doi.org/10.1111/j.1751-8369.2008.00074.x.

Hurum, J.H., Engelschion, V.S., Okland, I., Bratvold, J., Ekeheien, C., Roberts, A.J., Delsett, L.L., Hansen, B.B., Mork, A., Nakrem, H.A., Druckenmiller, P.S. \& Hammer, O. 2018: The history of exploration and stratigraphy of the early to middle Triassic vertebrate bearing strata of Svalbard (Sassendalen Group, Spitsbergen). Norwegian Journal of Geology 98, 165-174.

https://dx.doi.org/10.17850/njg98-2-04.

Jenks, J.F., Monnet, C., Balini, M. Brayard, A. \& Meier, M. 2015: Biostratigraphy of Triassic Ammonoids. In Klug, C., Korn, D., De Baets, K., Kruta, I. \& Mapes, R.H. (eds.): Ammonoid Paleobiology: From macroevolution to paleogeography, Topics in Geobiology 44, pp. 329-388. https://doi.org/10.1007/978-94-017-9633-0_13.

Maxwell, E.E. \& Kear, B.P. 2013: Triassic ichthyopterygian assemblages of the Svalbard archipelago: a reassessment of taxonomy and distribution. Geologiska Föreningen i Stockholm Förhandlingar 135, 1-10. https://doi.org/10.1080/11035897.2012.759145.

Mørk, A., Elvebakk, G., Forsberg, A.W., Hounslow, M.W., Nakrem, H.A., Vigran, J.O. \& Weitschat, W. 1999: The type section of the Vikinghøgda Formation: a new Lower Triassic unit in central and eastern Svalbard. Polar Research 18, 51-82. https://doi.org/10.3402/polar.v18i1.6558.

Nakrem, H.A., Orchard, M.J., Weitschat, W., Hounslow, M.W., Beatty, T.W. \& Mørk, A. 2008: Triassic conodonts from Svalbard and their Boreal correlations. Polar Research 27, 523-539. https://doi.org/10.1111/j.1751-8369.2008.00076.x.

Nicoll, R.S., Metcalfe, I. \& Wang, C. 2002: New species of the conodont genus Hindeodus and the conodont biostratigraphy of the PermianTriassic boundary interval. Journal of Asian Earth Sciences 20, 609631. https://doi.org/10.1016/S1367-9120(02)00021-4.

Ogg, J.G., Huang, C. \& Hinnov, L. 2014: Triassic timescale status: a brief overview. Albertiana 41,3-30.

Orchard, M.J. 2007: Conodont diversity and evolution through the latest Permian and Early Triassic upheavals. Palaeogeography, Palaeoclimatology, Palaeoecology 252, 93-117. https://doi.org/10.1016/j.palaeo.2006.11.037.

Orchard, M.J. 2008: Lower Triassic conodonts from the Canadian Arctic, their intercalibration with ammonoid-based stages and a comparison with other North American Olenekian faunas. Polar Research 27,393-412. https://doi.org/10.1111/j.1751-8369.2008.00072.x.

Orchard, M.J. 2010: Triassic conodonts and their role in stage boundary definition. In Lucas, S.G. (ed.): The Triassic Timescale, Geological Society of London Special Publications 334, pp. 139161. https://doi.org/10.1144/SP334.7.

Orchard, M.J. \& Zonneveld, J.P. 2009: The Lower Triassic Sulphur Mountain Formation in the Wapiti Lake area: lithostratigraphy, conodont biostratigraphy, and a new biozonation for the lower Olenekian (Smithian). Canadian Journal of Earth Sciences 46, 757790. https://doi.org/10.1139/E09-051.

Song, H., Wignall, P.B., Chen, Z.Q., Tong, J., Bond, D.P.G., Lai, X., Zhao, X., Jiang, H., Yan, C., Niu, Z., Chen, J., Yang, H. \& Wang, Y. 2011: Recovery tempo and pattern of marine ecosystems after the endPermian mass extinction. Geology 39, 739-742. https://doi.org/10.1130/G32191.1.

Stensiö, E.A. 1921: Triassic fishes from Spitsbergen. Part I. Adolf Holzhausen, Vienna, 307 pp.

Tozer, E.T. 1965: Lower Triassic stages and ammonoid zones of Arctic Canada. Geological Survey of Canada Paper 65-12, 1-14. https://doi.org/10.4095/100985.
Vigran, J.O., Mangerud, G., Mørk A., Worsley, D. \& Hochuli, P.A. 2014: Palynology and geology of the Triassic successions of Svalbard and the Barents Sea. Geological Survey of Norway Special Publication 14, Trondheim, $274 \mathrm{pp}$.

Weitschat, W. \& Dagys, A.S. 1989: Triassic biostratigraphy of Svalbard and a comparison with NE-Siberia. Mitteilungen aus dem Geologisch-Paläontologischen Institut der Universität Hamburg 68, 179-213.

Wignall, P., Bond, D.P.G., Sun, Y., Grasby, S., Beauchamp, B., Joachimski, M. \& Blomeier, D. 2016: Ultra-shallow-marine anoxia in an Early Triassic shallow-marine clastic ramp (Spitsbergen) and the suppression of benthic radiation. Geological Magazine 153, 316331. https://doi.org/10.1017/S0016756815000588.

Wiman, C. 1910: Ichthyosaurier aus der Trias Spitzbergens. Bulletin of the Geological Institution of the University of Uppsala 10, 124-148.

Wiman, C. 1928: Eine neue marine Reptilien-Ordnung aus der Trias Spitzbergens. Bulletin of the Geological Institution of the University of Uppsala 22, 183-196.

Wiman, C. 1933: Über Grippia longirostris. Nova Acta Regiae Societatis Scientiarum Upsaliensis 9, 19 pp. 